Journal of Biotechnology and Strategic Health Research

\author{
Derleme / Review
}

http://dergipark.org.tr/tr/pub/bshr

\title{
Kulak Burun Boğaz Hekimliği Açısından COVID-19 Salgını
}

\author{
COVID-19 Outbreak in Terms of Otorhinolaryngology
}

\section{\O ğuz Kadir Eğilmez, (D) Mahmut Sinan Yılmaz}

Sakarya Üniversitesi Eğitim ve Araştırma Hastanesi, KBB Kliniği, Sakarya

ORCID ID: Oğuz Kadir Eğilmez 0000-0001-9623-9152, M. Sinan Yllmaz 0000-0002-5323-0059

*Sorumlu Yazar / Corresponding Author: Op. Dr. Oğuz Kadir Eğilmez, e-posta / e-mail: oguzegilmez@gmail.com

Geliş Tarihi / Received : 21-04-2020 Kabul Tarihi / Accepted: 25-04-2020 Yayın Tarihi / Online Published: 30-04-2020

Atıf Gösterimi/How to Cite: Eğilmez K.O., Yılmaz M.S. Kulak Burun Boğaz Hekimliği Açısından COVID-19 Salgını, J Biotechnol and Strategic Health Res. 2020;1(Özel Sayı):140-146

$\ddot{\mathrm{O} z}$

Yeni koronavirüs hastalığı-2019 (COVID-19), SARS-CoV-2 tarafından meydana gelen ve solunum salgıları ile insandan insana yayılan oldukça bulaşıcı bir zoonozdur. Dünya Sağlık Örgütü (WHO) tarafından halk sağlığı acil durumu olarak ilan edilen bu hastalıkta sağlık çalışanları enfekte nüfusun \%3.8 ila \%20'sini temsil eder; \%15'i ciddi şikayetler geliştirecek ve muhtemelen aralarında çoğu hayatını kaybedecektir. Çoğu hastada belirgin belirti ve semptomların (ateş/solunum) olmaması cerrahlar için gerçek bir risk oluşturur. Bu nedenle tüm hastaları değerlendirirken solunum koruyucu stratejiler uygulamalıdırlar. Aerodinamik salgıları aerosol haline getirme potansiyeline sahip tüm müdahalelerden kaçınılmalıdır veya sadece zorunlu olduğunda kullanılmalıdır. Açıklanan prosedürler, COVID-19 salgını sırasında sağlık çalışanlarının güvenliğini korumaya çalışmak için gereklidir. Özellikle, Kulak Burun Boğaz (KBB) uzmanları, baş ve boyun ve maksillofasiyal cerrahlar, COVID-19 pozitif hastalara müdahale ederken en büyük enfeksiyon riskine maruz kalmaktadırlar ve bunların korunması mevcut durumlarda bir öncelik olarak düşünülmelidir. Bu derlemede COVID-19 pandemisinde KBB hekimlerinin karşılaşabileceği riskler, bunlarla ilgili önlemler ve bu hastalı̆̆ın seyrinde ortaya çıkabilen bazı önemli semptomlar üzerinde durulacaktır.

Anahtar COVID-19, Kulak Burun Boğaz, Anosmi, Agezi

Kelimeler

Abstract

New coronavirus disease-2019 (COVID-19) is a highly contagious zoonosis that occurs by SARS-CoV-2 and spreads from person to person with respiratory secretions. In this disease, which is declared a public health emergency by the World Health Organization (WHO), health workers represent $3.8 \%$ to $20 \%$ of the infected population; $15 \%$ will develop serious complaints, and most will probably die among them. The absence of obvious signs and symptoms (fever / breathing) in most patients poses a real risk for surgeons. Therefore, they should apply respiratory protective strategies when evaluating all patients. All interventions with the potential to aerosolize aerodynamic secretions should be avoided or used only when mandatory. The procedures described are necessary to try to protect the safety of healthcare workers during the COVID-19 outbreak. In particular, Otorhinolaryngology specialists, head and neck and maxillofacial surgeons are exposed to the greatest risk of infection when responding to COVID-19 positive patients, and their protection should be considered a priority in current situations. In this review, the risks that otorhinolaryngologist may encounter in the COVID-19 pandemic, precautions related to them and some important symptoms that may occur in the course of this disease will be discussed.

Keywords COVID-19, Otorhinolaryngology, Anosmia, Ageusia 


\section{GíRiş}

İlk kez Aralık 2019'da, Çin'in Hubei eyaleti Wuhan'da etiyolojisi bilinmeyen bir pnömoni salgını bildirildi. ${ }^{1}$ Dünya Sağlık Örgütü (WHO) tarafından Coronavirus hastalığı 2019 (COVID-2019) olarak adlandırılan bu hastalık 15 Nisan 2020 itibariyle dünya çapında 1.850 .000 kişiyi etkileyerek 116.000 'den fazla kişinin ölümüne sebep olmuştur. ${ }^{2}$ Etken ajanın, Şiddetli Akut Solunum Sendromu (SARS) ve Orta Doğu Solunum Sendromu (MERS) virüsleriyle yakından ilişkili yeni bir Coronavirüs (orijinal olarak 2019 yeni Coronavirus veya 2019-nCoV olarak adlandırıldığı) olduğu belirlendi ve SARS-CoV-2 olarak adlandırıldı. ${ }^{3}$ Tam bulaşma yolu net olmamakla birlikte, artan kanttlar, Kulak Burun Boğaz (KBB) uzmanlarının üst aerodigestif kanaldaki yüksek viral yük ve ağız boşluğunun, orofarenksin, nazal kavitelerin ve nazofarenksin sık muayenesi ve enstrümantasyonu nedeniyle mesleki SARS-CoV-2 maruziyeti riskinin arttığını göstermektedir. Nitekim COVID-19 ve SARS salgınları sırasında ilk doktor ölümü KBB uzmanları olarak bildirilmiştir. ${ }^{4} \mathrm{Bu}$ derlemede COVID-19 ile ilgili kısa bir bilgilendirmenin ardından bu hastalığın KBB etkileri ve KBB hekimlerinin nasıl korunması gerektiği ve operasyonel yaklaşım tavsiyeleri ile ilgili bilgiler aktarılacaktır.

\section{SARS-CoV-2}

Tüm Coronavirüsler gibi, SARS-CoV-2 de zarfll, pozitif polariteli tek iplikçikli bir RNA virüsüdür. Dizi analizi SARS Coronavirüs'e (SARS-CoV) \%76.9 homoloji ve yarasa Coronavirus BatCoVRaTG13'e (RaTG13) \%96. ${ }^{4}$ homoloji göstermiştir; bu da SARS-CoV-2'nin bir zoonotik enfeksiyonun sonucu olduğunu göstermektedir. ${ }^{1}$ Viral spike (S) proteini, SARS-CoV ile aynı hücresel reseptör, anjiyotensin dönüştürücü enzim II (ACE2) ile etkileşime girer, ancak SARS-CoV-2 S proteini, RaTG13 hariç bilinen diğer tüm Coronavirüslerden önemli dizi farklılığına sahiptir. Önemli olarak, SARS-CoV-2 2-3 R0 ile yüksek derecede bulaşabilir gibi görünmektedir, yani enfekte olmuş her kişi çevresindeki 2-3 ek insana bulaştırabilir. ${ }^{5}$ Solunum damlacıklarının ana bulaşma yolu olduğu varsayılırken, kanıtlar virüsün fekal-oral yoldan ve konjonktiva yoluyla da yayılabileceğini düşündürmektedir. ${ }^{6}$ Daha önemlisi,
SARS-CoV-2'nin çevrede oldukça kararlı olduğu görülmektedir. Canlı virüs 3 saate kadar aerosollerde, 24 saate kadar gözenekli yüzeylerde (karton) ve 72 saate kadar gözeneksiz yüzeylerde (paslanmaz çelik, plastik) bulunabileceği bildirilmiştir.7 Bu çevresel stabilite, tek bir bireyin R0 tarafından beklenenden daha saf bireyleri enfekte ettiği nozokomiyal bulaşma ve "süper yayıcı" olayları riskini arttırır. ${ }^{7,8}$

COVID-19'un en sık bildirilen semptomlarl; öksürük (\%67.8), ateş (\%43.8), yorgunluk (\%38.1), artmış balgam üretimi (\%33.7), dispne (\%18.7), miyalji (\%14.9), boğazda yanma (\%13.9) ve titremedir (\%11.5). ${ }^{9}$ Bununla birlikte, son zamanlarda yapılan bazı analizler hiposmi veya anosmi ve disgezinin az tanınmış semptomlar olabileceğini göstermektedir. ${ }^{10,11}$ Laboratuvar testlerinde lökopeni (\%33.7) ve lenfopeni (\%83.2) gösterebilir; yüksek C-reaktif protein (\%60.7), D-dimer (\%46.4) ve laktat dehidrojenaz (\%41) seviyeleri ile transaminit ( \%20); ve azalmış prokalsitonin (\%5.5) saptanabilir. Toraks bilgisayarlı tomografisi (BT) buzlu cam opasiteleri, düzensiz gölgelenme ve interstisyel değişiklikler dahil vakaların \%86.2'sinde anormallik olduğunu göstermektedir. ${ }^{9}$ SARS-CoV-2, ortalama 5.1 günlük bir inkübasyon süresine sahip gibi görünmektedir, hastaların\%95'i maruziyetten sonra 2.2 ila 11.5 gün arasında semptom geliştirmektedir. ${ }^{12}$ Bununla birlikte, asemptomatik hastaların oldukça bulaşıcı olabileceğini kabul etmek, rutin hasta değerlendirmesi için bile kişisel koruyucu ekipman (KKE) kullanımına duyulan ihtiyacı vurgulamak son derece önemlidir. ${ }^{12,13}$

\section{KBB uzmanları için risk içeren durumlar}

Wuhan salgını istatistiklerine göre sağlık çalışanları enfekte olanların \%3.8'ini kapsamaktadır. Bunların \%14.8'inde ciddi hastalık mevcuttu ve genel mortalite oranı \%0.6 idi. ${ }^{14-16}$ Öte yandan, İtalya'da, görev yapan sağlık çalışanlarının ise \%20'sinin enfekte olduğu ve bazılarının öldüğü bildirilmiştir. ${ }^{17}$ Sağlık personeli gibi semptomatik hastalarla temas halinde olan kişiler enfeksiyona en duyarlı kişilerdir. En sık enfekte olan sağlık personelleri ise genel servislerde çalışanlardır. ${ }^{18}$ İnsandan insana yayılma, solunum sekresyonları yoluyla gerçekleşir (fekal-oral yayılma da doğrulanmış olmasına rağmen), bu 
nedenle aerodigestif sistem hastalıkları olan hastalara bakanlar (diş hekimleri, KBB uzmanları, baş ve boyun cerrahları, gastroenterologlar, gögüs hastalıkları uzmanları, solunum terapistleri, konuşma terapistleri ve enfeksiyon hastalıkları uzmanları) veya oftalmologlar enfekte olan en duyarlı sağlık çalışanlarıdır (risk oranı 2.13). ${ }^{14,19,20} \mathrm{Bu}$ nedenle, bu meslek gruplarında koruyucu önlemlere özel bir ihtiyaç olduğu ortadadir.

Solunum hastalığ önlemleri genellikle cerrahlar takip eder. Bununla birlikte, önemli sayıda hastada ateş veya solunum semptomları yoktur (\%13-30), bu nedenle cerrahlar tüm hastalar için solunum koruyucu stratejiler uygulamalıdır. Enfeksiyonun klasik semptomları ateş, kuru öksürük ve nefes darlığıdır. Sendrom nadiren klasik bir soğuk algınlığına benzer. Bununla birlikte, grip benzeri semptomları olan tüm hastalar için önlemler alınmalıdır. Dünyanın dört bir yanındaki merkezlerden yapılan son raporlar, anosmi ve disgezinin COVID-19 salgını ile ilişkili önemli semptomlar olduğunu göstermiştir. Özellikle anosmi, başka semptomları olmayan koronavirüs pozitif hastalarda tek belirti olarak görülebilmektedir. Bu nedenle, Amerikan Kulak Burun Boğaz Akademisi (AAO-HNSF), bu semptomların olası COVID-19 enfeksiyonu için tarama araçları listesine eklenmesini önermiştir. ${ }^{21}$

Nazofarinlaringoskopi, endotrakeal entübasyon, invaziv olmayan ventilasyon, transnazal endoskopik cerrahi ve yüksek hızlı el aletleri veya ultrasonik aletler gibi aerodinamik salg1ları aerosol haline getirme potansiyeli olan tüm prosedürler, enfeksiyon riskini arttırdığı için bu işlemlerden bu dönemde olabildiğince kaçınılmalıdır veya sadece zorunlu olduğunda kullanılmalıdır. ${ }^{14,22}$ Elektrokoter dumanı veya transoral lazer rezeksiyonu ile üretilen duman için herhangi bir potansiyel risk hakkında bilgi yoktur, ancak bu ayarlarda da uygun önlemlerin alınması makul olacaktır.

Virüsün özellikleri nedeniyle, günlük iş akışının standart koruyucu önlemleri enfeksiyonu engellemeye yetmemektedir. Bu nedenle belirli maskeler (N-95 veya FFP2 veya daha yüksek) veya elektrikli hava temizleyici solunum cihazı (PAPR), diğer KKE ve özel sterilizasyon önlemleri enfeksiyonu önlemek için mutlaka uygulanmalıdır. ${ }^{23,24}$ Bununla birlikte, bir vaka serisi, COVID-19 pozitif hastaların aerosolize sekresyonları ile temas eden ve standart KKE kullanan 41 sağlık çalışanının hiçbirinin bir enfeksiyon geliştirmediğini bildirmektedir. ${ }^{19,25}$ Standart tedbirler alındığında enfeksiyon oranının tedbir alınmayan veya yanlış kullanılardan çok daha düşük olduğu görülmektedir. Sağlık çalışanlarında görülen enfeksiyonun önemli nedenlerinden biri, KKE eksikliği ve doğru kullanımı konusunda eğitim eksikliği ile ilgili olabilir. ${ }^{16}$ Düzgün takip edilen standart önlemlerin, karmaşık koruma stratejilerinin hızlı bir şekilde uygulanmasından daha başarılı olduğu ileri sürülmüştür. ${ }^{19,26}$

Gebelik, 55 yaş üstü olmak, bazı kronik hastalıklar (kronik hepatit, böbrek hastalıkları, diabetes mellitus, otoimmün hastalıklar ve kanser) ciddi akut solunum sıkıntısı sendromu (ARDS) geliştirmek için risk faktörlerini temsil eder. Bu tarz hastalıkları olan veya hastalıktan etkilenen sağlık çalışanları enfekte hastalar için bakım yapmamalıdır. ${ }^{27}$

Hastalık sağlık çalışanlarına ayrıca fiziksel, zihinsel ve duygusal bir yük getirmektedir. ${ }^{28}$ Enfekte hastalara ve enfeksiyon için "şüpheli” kabul edilen hastalara bakan doktorların çoğu daha çabuk tükenir. Ayrıca sağlık kaygısı günlük yaşamda yaygın olarak görülür, ancak bulaşıcı hastalık salgınları zamanlarında, bu durum zararlı etkiler üretebilir. Bugün, COVID-19'un klinik seyri, komplikasyon oranı ve mortalitesi hakkında doğru, ancak kimi zaman da yanlış bilgiler, medya ve sosyal ağlar aracılığıyla sürekli vurgulanmakta ve yaygınlaşmaktadır. Bu duyumların yanlış yorumlanması, hastalığın sonuçları hakkında yanlış inançlar ve hastalık psikolojisi ile baş edememe ile hasta olmak istememe kaygısının sıklığı ve şiddeti artabilir. ${ }^{29,30}$ Daha fazla bilgi alındıkça ve daha fazla bilgi geldikçe, aşırı kaygı rasyonel kararlar verme yeteneğinin kaybına yol açar. Özellikle cerrahlar için bu durumun iki kutupsal etkisi olabilir; ilk olarak, bazı insanlar doktorları bir bulaşma kaynağı olarak görebilir ve onlardan kaçınabilir, ikincisi, diğer insanlar onları güvenlik kaynağı olarak görebi- 
lir ve tekrar tekrar ziyaret ederek sağlık hizmetlerine daha fazla yük bindirebilir. Her iki durum da cerrahlar için riski arttırır: ilk durumda, halka açık alanlarda tehdit edilebilirler ve ikincisinde ise yardım edebilme kapasiteleri aşılmış olabilir.

\section{KBB uzmanları için dikkat edilmesi gerekenler}

Fleksible fiberoptik laringoskopinin (FFL) rutin kullanımı s1rasında SARS-CoV-2 virüs bulaşma riskini azaltmak için en iyi yöntem konusunda resmi bir kılavuz bulunmamaktadır. Yurtdışı kaynaklarda da belirtildiği gibi ve Türk Kulak Burun Boğaz ve Baş Boyun Cerrahisi Derneği'nin de önerisi ile bulaş riskini azaltmak için gerekli olduğu düşünülmedikçe, tüm endoskopilerin ertelenmesi de dahil olmak üzere bazı önerilerde bulunulmaktadır. ${ }^{31,32}$ Uygulayıc1 FFL yaparken tek kullanımlık bir önlük, N95 maskesi ve yüz siperi takmalıdır.4 Wuhan'daki bir KBB grubu, 4.148 ateşli ve 22 onaylanmış COVID vakasında hastadan enfeksiyondan kaçınabilmek için klinik ve ameliyathane programındaki değişiklikleri ve aşağıdaki yönergeleri kullandılar;:

1. Hastaların burun boşluğu ve farinks mukozasına öksürük ve hapşırma reflekslerini azaltmak için iyi anestezi uygulanmalıdır

2. Aerosol üretimini en aza indirmek için spreyler yerine jel tipi topikal anestezikler kullanılmalıdır

3. Öksürme ve hapşırma olasılığını azaltmak için en küçük çapda optikler kullanılmalıdır. ${ }^{33}$

Şu an için Sağlık Bakanlığı tarafından pandemi hastanesi olarak belirlenen hastanemizde KBB kliniği olarak tonsillektomi, mastoidektomi, sinüs cerrahisi ve diğer hava yolu prosedürleri gibi dokuları aerosolleştirebilecek acil olmayan tüm müdahalelerin ertelenmesine karar verildi. Böyle bir cerrahi işlem uygulanması gerektiğinde mutlaka uygun KKE giyilmelidir. Vaka seçimi ve uygulanması ile ilgili Stanford Üniversitesi KBB Kliniğinin bir algoritması mevcuttur (Şekil 1).

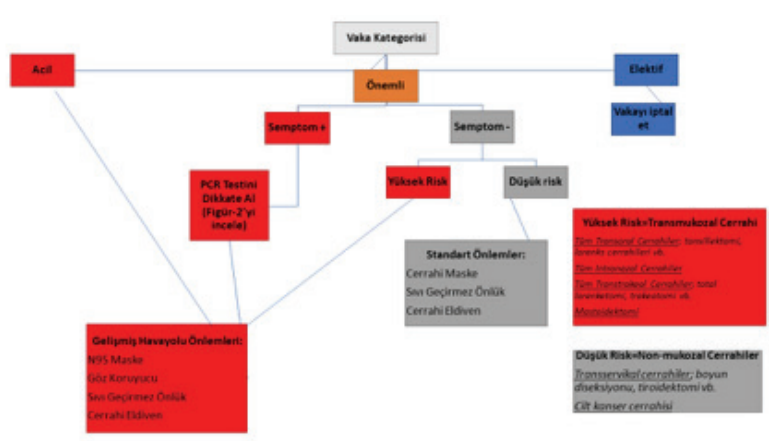

COVID-19 testi daha yaygın hale geldiğinden, yazarlar tüm ameliyat öncesi hastaların testlerinin daha yaygın hale geleceğini umarak uygun KKE'yi içeren ikinci bir algoritmanın da kullanılacağını düşündüklerini ifade etmektedirler (Şekil 2). ${ }^{31}$

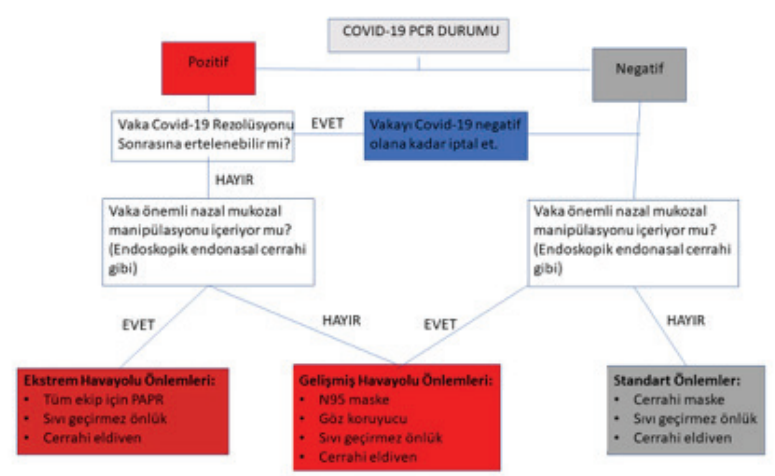

Türk Kulak Burun Boğaz ve Baş Boyun Cerrahisi Derneği de elektif veya aciliyet gerektirmeyen her türlü cerrahi işlemlerin ertelenmesi gerektiğini vurgulamaktadır. Ancak acil şartlar altında COVID-19 pozitif veya şüpheli bir hastaya epistaksis müdahalesi, trakeotomi vb. işlemler yapılacaksa özel önlemler alınması gerektiğini ifade etmektedir. ${ }^{32}$

Olası/kesin COVID-19 vakalarında mecbur olmadıkça havayolu (nazal, nazo-orofarengeal, larenks ve trakea) cerrahisinden kaçınılmalıdır. Mecburi durumlarda olası aerosol bulaşını azaltmak için havayollarının bir örtü ile kapatılması uygun olacaktır. Girişimi cerrahi ekipten en deneyimli kişinin yapması ve cerrahi PAPR kullanması önerilmektedir. ${ }^{32}$

Literatürde topikal anestezi veya sedasyon altında yapılacak epistaksis kontrolü gibi işlemler için ayrı bir standart tanımlanmamıştır. Böyle vakalarda nazofarengeal kültür alma pro- 
sedürü uygulanabilir; yani müdahale eden kişiler mutlaka tek kullanımlık önlük, N95/FFP2 veya N99/FFP3 maske, siper, gözlük ve çift kat eldiven kullanmalıdır. Sadece ciddi, tekrarlayan ve önemli bir sağlık sorunu oluşturma potansiyeli olan kanamalara müdahale edilmelidir. Hafif şiddetteki kanamalar tekrarlayıcı da olsa tıbbi müdahale tercih edilmemelidir. Bunlara sadece nazal nemlendirici, topikal dekonjestan kullanımı, istirahat ve gerekiyorsa antihipertansif tedavinin düzenlenmesi ve mümkünse antiagregan ilaçların kesilmesi gibi daha konservatif yöntemlerle yaklaşılması önerilir. Topikal anestezi sağlanması ve pıhtıların temizlenmesi yüksek oranda virüs bulaşı yapabileceği unutulmamalıdır. Mümkün olan en hızlı şekilde selülöz bazlı hazır nazal anterior tampon yerleştirilmeli, kanama kontrol edilemez ise tamponlar çıkarılıp koanal balon yerleştirilip, yeni bir çift anterior nazal tampon konulmalıdır. Bu süreçte oksijen satürasyonu düşme ihtimalinden anestezi ekibi bilgilendirilerek entübasyon ve mekanik ventilatör ihtiyacı konuşulmalı, girişim mümkünse yoğun bakım şartlarında yapılmalıdır. ${ }^{32}$

Bu süreçte trakeotomi yerine mümkün olduğu kadar entübasyon tercih edilmelidir. Eğer çok gerekiyorsa acil trakeotominin aksine entübe hastaya ve perkutan prosedür uygulanarak yapılmalıdır. Uzamıș entübasyon gibi elektif trakeotomi endikasyonlarından kaçınılması gerektiği önerilmektedir. ${ }^{32}$ Daha önceki SARS salgını sırasında trakeotomi için cerrahi hususları inceleyen bir derlemede enfekte bir hastada açık trakeotomi planlanırken bulaş riskini en aza indirmek için uygulanan metodlar ve KKE olarak kullanılan malzemeler ile operasyonları yapan ekiplerin birimleri gibi bazı önemli perioperatif hususlara vurgu yapılmıştır (Tablo-1). ${ }^{34}$

İtalya'dan bildirilen bir yazıda da trakeotomi için "CORONA" adımları şeklinde kısaltma yapılarak hatırlanması kolay, eşlik etmesi gereken uygun adımlar oluşturulmuştur. Burada Covering yourself (C): Kendini koru; Operating Room setting (OR): Ameliyathane düzeni; Opening the trachea (O): Trakeanın açılması; Nursing and Airway Management (NA): Hemşirelik ve Havayolu Yönetimi olarak belirtilmiş ve yazıda bunlarla ilgili görseller verilmiştir. ${ }^{35}$

\begin{tabular}{|c|c|c|c|}
\hline \multirow[b]{2}{*}{ Özellik } & \multicolumn{3}{|l|}{ Vaka Serileri } \\
\hline & Chee ve ark. & Tien ve ark. & Wei ve ark. \\
\hline Kurum & $\begin{array}{l}\text { Tan Tock Seng } \\
\text { Hastanesi, } \\
\text { Singapur }\end{array}$ & $\begin{array}{l}\text { Sunnybrook ve } \\
\text { Kadın Sağlık } \\
\text { Bilimleri Merke- } \\
\text { zi, Toronto, } \\
\text { Ontario, Kanada }\end{array}$ & $\begin{array}{l}\text { Kraliçe Mary } \\
\text { Hastanesi, Hong } \\
\text { Kong, SAR, Çin }\end{array}$ \\
\hline $\begin{array}{l}\text { Gerçekleştirilen } \\
\text { trakeostomi } \\
\text { sayısı }\end{array}$ & 15 & 3 & 3 \\
\hline $\begin{array}{l}\text { Ameliyat } \\
\text { sirasinda bariyer } \\
\text { önlemleri }\end{array}$ & $\begin{array}{l}\text { Standart KKEa, } \\
\text { ayakkabı kilıfları } \\
\text { ve motorlu } \\
\text { hava temizleyici } \\
\text { solunum sistemi } \\
\text { (PAPR) }\end{array}$ & $\begin{array}{l}\text { Standart KKEa } \\
\text { ve Stryker T4 } \\
\text { Koruma Sistemi }\end{array}$ & $\begin{array}{l}\text { Standart KKEa, } \\
\text { ayakkabı } \\
\text { örtüleri ve } \\
\text { gözlük dişından } \\
\text { takılabilen ek } \\
\text { plastik yüz } \\
\text { siperi }\end{array}$ \\
\hline Ameliyat ortamı & $\begin{array}{l}\text { Yoğun bakımda } \\
\text { negatif basınç } \\
\text { odası }\end{array}$ & $\begin{array}{l}\text { Yoğun bakımda } \\
\text { negatif basınç } \\
\text { odası }\end{array}$ & $\begin{array}{l}\text { Yoğun bakımda } \\
\text { negatif basınç } \\
\text { odası ya da } \\
\text { ameliyathane }\end{array}$ \\
\hline $\begin{array}{l}\text { Aerosolizasyonu } \\
\text { azaltmak için } \\
\text { intraoperatif } \\
\text { adımlar }\end{array}$ & $\begin{array}{l}\text { Hastanın tam } \\
\text { paralizisi, } \\
\text { trakeotomiden } \\
\text { önce mekanik } \\
\text { ventilasyon } \\
\text { durduruldu, } \\
\text { işlem sırasında } \\
\text { sinırlı emiş } \\
\text { yapıldı, trake- } \\
\text { otomi dışında } \\
\text { diatermiden } \\
\text { kaçınılmadı. }\end{array}$ & $\begin{array}{l}\text { Hastanın tam } \\
\text { paralizisi, } \\
\text { trakeotomiden } \\
\text { önce mekanik } \\
\text { ventilasyon } \\
\text { durduruldu, } \\
\text { trakea girildik- } \\
\text { ten sonra emiş } \\
\text { kullanılmadı, } \\
\text { mümkün } \\
\text { olduğunca } \\
\text { diyatermiden } \\
\text { uzak duruldu. }\end{array}$ & $\begin{array}{l}\text { Hastanın tam } \\
\text { paralizisi, } \\
\text { trakeotomiden } \\
\text { önce mekanik } \\
\text { ventilasyon } \\
\text { durduruldu, } \\
\text { prosedür } \\
\text { boyunca emiş } \\
\text { kullanılmadı, } \\
\text { diyatermiden } \\
\text { mümkün } \\
\text { olduğunca } \\
\text { kaçınıldı. }\end{array}$ \\
\hline $\begin{array}{l}\text { Cerrahi ekip } \\
\text { üyeleri }\end{array}$ & $\begin{array}{l}\text { Tüm trakeos- } \\
\text { tomileri yapan } \\
\text { tek bir ekip: } \\
\text { deneyimli cer- } \\
\text { rah, deneyimli } \\
\text { anestezi uzmanı, } \\
1 \text { hemșire ve } 1 \\
\text { cerrahi asistanı }\end{array}$ & $\begin{array}{l}\text { Kıdemli travma } \\
\text { cerrahı ve } \\
\text { mevcut en } \\
\text { kıdemli cerrahi } \\
\text { personeli, yoğun } \\
\text { bakım aneste- } \\
\text { zisti ve sirküle } \\
\text { hemşire veya } \\
\text { steril giyinen } \\
\text { hemşire yok }\end{array}$ & $\begin{array}{l}\text { Tek cerrah, } 1 \\
\text { yoğun bakım } \\
\text { uzmanı ve } \\
1 \text { yardımcı } \\
\text { personel veya } \\
\text { hemşire }\end{array}$ \\
\hline \multicolumn{4}{|c|}{$\begin{array}{l}\text { KKE: Kişisel Koruyucu Ekipman } \\
\text { a Standart KKE, bir N95 maske, cerrahi kep, gözlük, cerrahi önlük ve } \\
\text { eldivenlerden olușur. }\end{array}$} \\
\hline
\end{tabular}

\section{Koronavirüs hastalığının bir bulgusu; koku ve tat alma bozukluğu}

COVID-19 enfeksiyonunun Avrupa’da yayılması ile hastalığın yeni bir atipik bulgusu vurgulanmaya başlanmıştır: koku ve tat alma bozukluğu. Üst solunum yolu viral enfeksiyonlarında koku alma bozukluğu görülmesi yeni bir durum değildir. Birçok virüs burun mukozasının inflamatuar reaksiyonu ve rinore gelişimi yoluyla olfaktör disfonksiyona (OD) yol açabilir; 
en bilinen ajanlar rinovirüs, parainfluenza Epstein-Barr virüsü ve bazı koronavirüslerdir. ${ }^{36,37}$ Bununla birlikte, COVID-19 enfeksiyonuna bağlı koku bozukluğu, rinore ile ilişkili olmadığı için yeni bir durum gibi görünmektedir. Son birkaç hafta içinde, bazı Avrupalı KBB uzmanları SARS-CoV-2 ile enfekte olmuş birçok hastanın rinore veya burun tıkanıklığı olmadan ciddi koku alma ve tat alma bozukluğu ile başvurduğunu gözlemlediler. Başlangıçta, bu hastaların bazılarında COVID-19'dan şüphelenilmedi, çünkü ateş, öksürük veya diğer sistemik şikayetleri yoktu. Avrupa'nın dört bir yanındaki KBB uzmanlarının sayısız raporlarıyla karşılaşan Uluslararası KBB Dernekleri Federasyonu (YO-IFOS), enfekte hastalarda koku alma ve tat bozukluğunu karakterize etmek için uluslararası bir epidemiyolojik çalışma yürütmüştür. Bu çalışma, hem koku hem de tat alma bozukluğunu Avrupa COVID-19 enfeksiyonunun klinik sunumunda anlamlı semptomlar olarak tanımlayan ilk çalışmadır. Sonuçlara dayanarak, enfekte hastaların diğer önemli şikayetleri olmadan sadece koku ve/ veya tat alma bozukluğu gösterebilecekleri bildirilmiştir. Yazarlar ani anosmi veya agezi, uluslararası bilim topluluğu tarafından COVID-19 enfeksiyonunun önemli belirtileri olarak tanınması gerektiğini bildirmişlerdir. ${ }^{38}$ Soler ve ark.'nın ${ }^{39}$ yaptığı derlemede bu konuyla ilgili bazı öneriler vardır;

1. Eşzamanlı semptomlardan bağımsız olarak ani koku ve/ veya tat kaybı şikayeti yaşayan hastalar COVID-19 için şüpheli olarak değerlendirilmelidir.

2. COVID-19'dan sonra akut koku ve tat kaybı olan hastalar viral ilişkili koku kaybına sahip olabileceklerini varsaymalidir.

3. Aktif COVID-19 olan bir hastada akut koku kaybını tedavi etmek için oral ve/veya topikal kortikosteroidler verilmemelidir.

4. Koku alma eğitimi terapisi, resmi tıbbi değerlendirmeden önce başlatılabilir.

5. Sürekli koku kaybı olan hastalar için, bir KBB uzmanı tarafından resmi bir değerlendirme, halk sağlı̆̆ı açısından pandemi durumu güvenli olduğunda düşünülmelidir.

Derlemede geçen koku alma eğitimine kısaca değinecek olursak, bu teknik koku alma duyumuzu sağlamaktan sorumlu sinirlerin egzersiz yoluyla güçlendirilebileceği fikrine dayanmaktadır. Koku alma eğitiminin birden fazla klinik çalışmada etkili olduğu gösterilmiştir. Bununla birlikte, bu sonuçların birden fazla hastada ortalaması alınır ve her bir bireyin farklı miktarlarda iyileşebileceği unutulmamalıdır. Kokudaki iyileşme genellikle yavaştır ve aylar boyunca hatta 2 yıla kadar bile uzayabilmektedir. ${ }^{39}$

\section{Koku alma terapisinde teknik ${ }^{39}$}

A. Eğitim dört farklı maddenin kokusundan oluşur: gül, okaliptüs, limon ve karanfil; günde iki kez ve her gün yapılmalıdır.

1. Bir koku seçin ve bir zamanlar nasıl koktuğunu hatırlamaya çalışırken yaklaşık 15 saniye koklayın.

2. Yaklaşık 10 saniye dinlenin.

3. Bir sonraki kokuyu yaklaşı 15 saniye boyunca koklayın.

4. Yaklaşık 10 saniye dinlenin.

5. Dört kokunun tümü örneklenene kadar tekrarlayın.

B. Üç ay sonra yeni bir koku setine geçin: mentol, kekik, mandalina ve yasemin ve onlarla yukarıda açıklandığı gibi egzersiz yapın.

C. Üç ay sonra yeni bir koku grubuna geçin: yeşil çay, bergamot, biberiye ve gardenya ve onlarla yukarıda açıklandığı gibi tekrar eğitin.

\section{SONUÇ}

KBB doktorları COVID-19 belirtileri olan hastaları görebilen ve branşının doğası nedeniyle enfeksiyon riski önemli ölçüde yüksek olan sağlık hizmeti sağlayıcıları olarak önemli bir konuma sahiptir. En yüksek riskli cerrahi alanın üyeleri olarak, yukarıda belirtilen belirti ve semptomların farkında olmak ve özellikle acil otolarengolojik müdahale gerektiren hastalarda şüpheli vakalara derhal müdahele etmek bizim sorumluluğumuzdadır. Uygulamalar ve öneriler yeni verilere, test ve kaynakların kullanılabilirliğine bağlı olarak gelişecektir.

Çalışmayı maddi olarak destekleyen kişi/kuruluş yoktur ve yazarların herhangi bir çıkar dayalı ilişkisi yoktur. 


\section{Kaynaklar}

1. Zhou P, Yang XL, Wang XG, et al. A pneumonia outbreak associated with a new coronavirus of probable bat origin. Nature. 2020; 579(7798): 270-273.

2. Johns Hopkins University \& Medicine. Coronavirus resource center. 2020; https://coronavirus.jhu.edu/. Accessed April 15, 2020.

3. Gorbalenya AE, Baker SC, Baric RS, et al. Severe acute respiratory syndrome-related coronavirus: the species and its viruses - a statement of the Coronavirus Study Group. bioRxiv. 2020. DOI: https://doi.org/10.1101/2020.02.07.937862

4. Chan JYK, Wong EWY, Lam W. Practical Aspects of Otolaryngologic Clinical Services During the 2019 Novel Coronavirus Epidemic: An Experience in Hong Kong. JAMA Otolaryngol Head Neck Surg. 2020. doi:10.1001/jamaoto.2020.0488

5. Liu Y, Gayle AA, Wilder-Smith A, et al. The reproductive number of COVID-19 is higher compared to SARS coronavirus. J Travel Med. 2020; 27(2). pii: taaa021. doi: 10.1093/jtm/ taaa021.

6. Li JO, Lam DSC, Chen Y, et al. Novel Coronavirus disease 2019 (COVID-19): The importance of recognising possible early ocular manifestation and using protective eyewear. $\mathrm{Br} J$ Ophthalmol. 2020; 104(3): 297-298.

7. van Doremalen N, Bushmaker T, Morris DH, et al. Aerosol and Surface Stability of SARSCoV-2 as Compared with SARS-CoV-1. N Engl J Med. 2020; 382(16): 1564-1567. doi: 10.1056/NEJMc2004973.

8. Liu Y, Eggo RM, Kucharski AJ. Secondary attack rate and superspreading events for SARSCoV-2. Lancet. 2020; 395(10227): e47.

9. Guan WJ, Ni ZY, Hu Y, et al. Clinical Characteristics of Coronavirus Disease 2019 in China. N Engl J Med. 2020. doi: 10.1056/NEJMoa2002032

10. Mao L, Wang M, Chen S, et al. Neurological manifestations of hospitalized patients with COVID-19 in Wuhan, China: a retrospective case series. medRxiv. 2020. DOI: https://doi. org/10.1101/2020.02.22.20026500

11. Hopkins C, Kumar N. Loss of sense of smell as a marker of COVID-19 infection. 2020; https://www.entuk.org/loss-sense-smell-marker-covid-19-infection. Accessed March 21, 2020.

12. Lauer SA, Grantz KH, Bi Q, et al. The Incubation Period of Coronavirus Disease 2019 (COVID-19) From Publicly Reported Confirmed Cases: Estimation and Application. Ann Intern Med. 2020

13. Bai Y, Yao L, Wei T, et al. Presumed Asymptomatic Carrier Transmission of COVID-19. JAMA. 2020.

14. Meng L, Hua F, Bian Z. Coronavirus Disease 2019 (COVID-19): Emerging and Future Challenges for Dental and Oral Medicine. J Dent Res. 2020: 22034520914246. doi:10.1177/0022034520914246

15. Wu Z, McGoogan JM. Characteristics of and Important Lessons from the Coronavirus Disease 2019 (COVID-19) Outbreak in China: Summary of a Report of 72314 Cases From the Chinese Center for Disease Control and Prevention. JAMA. 2020.doi:10.1001/ jama.2020.2648

16. Wang J, Zhou M, Liu F. Exploring the reasons for healthcare workers infected with novel coronavirus disease 2019 (COVID-19) in China. J Hosp Infect. 2020. doi:10.1016/j. jhin.2020.03.002

17. Remuzzi A, Remuzzi G. COVID-19 and Italy: what next? Lancet. 2020. doi:10.1016/S01406736(20)30627-9

18. Koh D. Occupational risks for COVID-19 infection. Occup Med (Lond). 2020; 70: 3-5. doi:10.1093/occmed/kqaa036

19. Ran L, Chen X, Wang Y, et al. Risk Factors of Healthcare Workers with Corona Virus Disease 2019: A Retrospective Cohort Study in a Designated Hospital of Wuhan in China. Clin Infect Dis. 2020. doi:10.1093/cid/ciaa287

20. Lai THT, Tang EWH, Chau SKY, et al. Stepping up infection control measures in ophthalmology during the novel coronavirus outbreak: an experience from Hong Kong. Graefes Arch Clin Exp Ophthalmol. 2020. doi:10.1007/s00417-020-04641-8
21. https://www.entnet.org/content/aao-hns-anosmia-hyposmia-and-dysgeusia-symptoms-coronavirus-disease

22. Patel Z, Fernandez-Miranda J, Hwang P, et al. Precautions for endoscopic transnasal skull base surgeryduring the covid-19 pandemic. 202024 March. Available from: https://www. entnet.org/sites/default/files/uploads/covid 19_endosb_lettertoeditor_neurosurgery_update3.23.20.pdf

23. Rimmer A. Covid-19: What's the current advice for UK doctors? BMJ. 2020; 368:m978. doi:10.1136/bmj.m978

24. Schwartz J, King CC, Yen MY. Protecting Health Care Workers during the COVID-19 Coronavirus Outbreak-Lessons from Taiwan's SARS response. Clin Infect Dis. 2020. doi:10.1093/cid/ciaa255

25. $\mathrm{Ng}$ K, Poon BH, Kiat Puar TH, et al. COVID-19 and the Risk to Health Care Workers: A Case Report. Ann Intern Med. 2020. doi:10.7326/L20-0175

26. Maxwell DN, Perl TM, Cutrell JB. "The Art of War" in the Era of Coronavirus Disease 2019 (COVID-19). Clin Infect Dis. 2020. doi:10.1093/cid/ciaa229

27. Li T. Diagnosis and clinical management of severe acute respiratory syndrome Coronavirus 2 (SARS-CoV-2) infection: an operational recommendation of Peking Union Medical College Hospital (V2.0). Emerg Microbes Infect. 2020; 9: 582-585. doi:10.1080/22221751 .2020 .1735265

28. Huh S. How to train the health personnel for protecting themselves from novel coronavirus (COVID-19) infection during their patient or suspected case care. J Educ Eval Health Prof. 2020; 17: 10.doi:10.3352/jeehp.2020.17.10

29. Asmundson GJG, Taylor S. How health anxiety influences responses to viral outbreaks like COVID-19: What all decision-makers, health authorities, and health care professionals need to know. J Anxiety Disord. 2020; 71: 102211.doi:10.1016/j.janxdis.2020.102211

30. Ioannidis JPA. Coronavirus disease 2019: the harms of exaggerated information and non-evidence-based measures. Eur J Clin Invest. 2020:e13222.doi:10.1111/eci.13222

31. Vukkadala N, Qian ZJ, Holsinger FC, et al. COVID-19 and the otolaryngologist - preliminary evidence-based review. Laryngoscope. 2020 Mar 26. doi: 10.1002/lary.28672. [Epub ahead of print]

32. https://www.kbb.org.tr/menu/saglik-profesyonellericin-110

33. Lu D, Wang $H, Y u R$, et al. Integrated infection control strategy to minimize nosocomial infection of corona virus disease 2019 among ENT healthcare workers. J Hosp Infect. 2020. doi:10.1016/j.jhin.2020.02.018

34. Tay JK, Khoo ML, Loh WS. Surgical Considerations for Tracheostomy During the COVID-19 Pandemic: Lessons Learned From the Severe Acute Respiratory Syndrome Outbreak. JAMA Otolaryngol Head Neck Surg. 2020. doi: 10.1001/jamaoto.2020.0764. [Epub ahead of print]

35. Pichi B, Mazzola F, Bonsembiante A, et al. CORONA-steps for tracheotomy in COVID-19 patients: A staff-safe method for airway management. Oral Oncol. 2020; 105:104682. doi: 10.1016/j.oraloncology.2020.104682. [Epub ahead of print]

36. Suzuki M, Saito K, Min WP, et al. Identification of viruses in patients with postviral olfactory dysfunction. Laryngoscope. 2007; 117(2): 272-277

37. van Riel D, Verdijk R, Kuiken T. The olfactory nerve: a shortcut for influenza and other viral diseases into the central nervous system. J Pathol. 2015; 235(2): 277-287. https ://doi. org/10.1002/path.4461

38. Lechien JR, Chiesa-Estomba CM, De Siati DR, et al. Olfactory and gustatory dysfunctions as a clinical presentation of mild-to-moderate forms of the coronavirus disease (COVID-19): a multicenter European study. Eur Arch Otorhinolaryngol. 2020. doi: 10.1007/ s00405-020-05965-1. [Epub ahead of print]

39. Soler ZM, Patel ZM, Turner JH, Holbrook EH. A primer on viral-associated olfactory loss in the era of COVID-19. Int Forum Allergy Rhinol. 2020. doi:10.1002/alr.22578. [Epub ahead of print] 